\title{
Stilistic Study Of Poetry Anthology "Aku Ingin Menjadi Peluru" Wiji Thukul's Works
}

\author{
Yuannisah Aini Nasution*1), Mei Nanda Sari ${ }^{2)}$ \\ 1,2), Al Washliyah University of Labuhan Batu, Rantauprapat \\ *Coresponding Author \\ Email :yuannisahaininst12@gmail.com
}

\begin{abstract}
This research focuses on study of diction, style of language, and imagery in the anthology of poetry "Aku ingin menjadi peluru" by Wiji Thukul. This research uses a qualitative approach in the form of qualitative narrative research using content analysis methods. The purpose of this research is to find out the depth of meaning in the document under study. This research uses qualitative research methods, namely the literary research method using stylistic research theory. The data source used in this study is the anthology of the poem "I want to be a bullet" by Wiji Thukul in 2004. The data collection technique in this study uses document analysis, which is to optimally utilize a set of procedures to draw valid conclusions and existing documents. Collecting data used in this research are by using library techniques, listening techniques, and note-taking techniques. The results of the analysis shows that stylistic forms found in "aku ingin jadi peluru" are (1) the choice of words (diction) using concrete words, (2) the use of synecdoche figure of speech, and (3) use of motion imagery.
\end{abstract}

Keywords: Stylistics, Anthology, and Poetry

\section{INTRODUCTION}

Literary works are created with imaginative language by choosing various kinds of beautiful words, so as to form a literary work that can give a message to people who are cultured, moral, and have noble character. Literary works are man-made life or literary creations. Life in a literary work is a life that has been colored by the attitude of the author, his educational background, his beliefs and so on.

Language is one of the most important elements in a literary work by Nurgiyantoro (in Munir et al, 2013: 2). In studying language in literary works, it is necessary to use language style research. Stylistics is a science that examines the use of language and style in Sudjiman's literary works (in Munir et al, 2013: 2).

Language is used as an author to be used as a means of expressing oneself in expressing the meaning of a work. Stylistic research in a literary work actually aims to examine aspects of the poetic formation of a literary work in the form of literary language which characterizes Stylistics which will build aspects of the beauty of literary works.

The more the use of stylistics, the more interesting the literary works produced will be. The author's proficiency in the use of stylistics will determine the weight and quality of the literary work created. In addition to the style of language, stylistic research must also pay attention to research in terms of diction (choice of words), imaging (image). Diction is a lexical element in Nurgiyantoro's style of language (in Munir et al, 2013: 3). Diction refers to the meaning of the use of certain words that are deliberately chosen by the author.

According to Pradopo (in Munir et al, 2013: 2), poetry is the most core literary statement. In contrast to other literary works, prose and drama, literary works in the form of poetry are concentrated and dense. The author does not reveal in detail what he wants to convey to his readers. 
Wiji Thukul is a poet who was born in Solo. Poets dealing with grassroots communities, rickshaw drivers, and factory workers are central figures in the theme of his poetry. Therefore, Wiji Thukul's poetry has its ups and downs for many small communities. As a result of the political and economic policies of the New Order government, poets often expressed economic disparities. This is the hallmark of Wiji Thukul's work. Indonesian is described using simple and easy to understand language. This is why this authoritarian poet became a feared and fugitive poet, and also for his activities as an activist. Finally, the distribution of his work was prohibited, and the scope of his activities was limited.

The stylistic study is reviewed in the anthology of Wiji Thukul's Poetry Aku Ingin Menjadi Peluru, chosen because Wiji Thukul's poems are full of various styles of language that will emerge as seen from the uniqueness of Wiji Thukul's poetry in presenting poetry with solid and strong diction, but looks familiar and unpretentious. The dictions used by Wiji Thukul are often heard and spoken in everyday life. Wiji Thukul's work is very easy to understand and read. Through his work, Wiji Thukul continues to rise and become a turning point in his life. Wiji Thukul's character and thoughts at that time were perhaps too bold. Readers can listen to his thoughts, as described in the Anthology of Poetry I Want to Be a Bullet. Through literature, Wiji Thukul "attacked" various violations committed by the New Order government and its institutions. Wiji Thukul (Wiji Widodo) also inspires the spirit of the marginalized to fight for their rights.

In general, this research focuses on knowing the use of language in literary works that use stylistic studies to find its aesthetic value. In particular, this study aims to determine the use of diction, language style, and imagery in Wiji Thukul's Poetry Anthology I Want to Be a Bullet, which focuses on poetry Untuk Adik, Bungan dan Tembok, Sajak Suara, Peringatan, Derita Sudah Naik Seleher, (Tanpa Judul), Puisi Menolak Patuh, Aku Masih Utuh dan Katakataku Belum Binasa, Monumen Bambu Runjing, Nyanyian Akar Rumput, Ucapkan Katakatamu, Catatan 88, Tanah, Sajak, dan Ibu.

The purpose of this research is to find out the diction in the anthology of the poem I Want to Be a Bullet by Wiji Thukul. Describes the style of language contained in the Anthology of the Poetry Aku Ingin Menjasi Peluru by Wiji Thukul. Describing the image in the Poetry Anthology Aku Ingin Menjasi Peluru by Wiji Thukul.

\section{RESEARCH METHODS}

\section{Research Design}

Researchers in compiling research instruments use the theory of Miles and Huberman in Sugiyono (2016) where the instrument or research tool is the researcher himself who functions to determine the focus of research, select informants as data sources, collect data, assess data quality, analyze data, interpret data and draw conclusions on the findings in order to obtain a valid instrument. In selecting respondents, researchers used structured interview techniques, while data collection techniques used interviews and documentation. In the validity of the data, this researcher uses source triangulation, namely comparing the results of interviews between primary sources and secondary sources so that in the end a final and valid conclusion is obtained.

\section{Place and time of research}

Research on literary stylistics Antontology of Poetry Aku Ingin Menjadi Peluru, a selection of poetry by Wiji Thukul, published by Indonesiatera, Magelang 2004 is a document analysis (content analysis), namely a document in the form of an anthology of poetry books. 
researchers, both in the campus library, as well as in local regional libraries that are in the environment around the research. This research was carried out from February to April 2021. This research was conducted over a period of approximately two months.

\section{Research methods}

The form of this research is a qualitative narrative using the method of content analysis or content analysis. The purpose of this content analysis is to find out the depth of meaning in the document under study. This research uses qualitative research methods, namely the literary research method using stylistic research theory.

\section{Research Instruments}

The instruments used in this study were interview guidelines given to principals, vice principals, teachers and students, as well as documentation guidelines ranging from school identity documentation, photos of research activities, during interviews.

\section{Data analysis technique}

In this study, the data collected will be processed so that the information obtained is then used as description material. Sources of data used in this study consisted of two kinds of sources, namely; Primary data and Secondary Data.

\section{Data collection technique}

The data collection technique in this study uses document analysis, which is to optimally utilize a set of procedures to draw valid conclusions and existing documents. Collecting data used in this study by using library techniques, listening techniques, and notetaking techniques.

\section{RESULTS AND DISCUSSION}

\section{- Analysis of the use of diction (word choice) Poetry Anthology Aku Ingin Menjadi Peluru by Wiji Thukul}

a. Poems of Monumen Bambu Runcing

In the poem, Monumen Bambu Runcing uses the word "jemu" which shows boredom because things are often done.

"di kakinya tak jemu juga"

"pedagang kaki lima berderet-deret"

b. Poems of Nyanyian Akar Rumput

Establishing the village referred to by the poet is a residence for the lower classes who were evicted by an upper class person, to be used as a location that provides benefits for the elite.

"mendirikan kampung"

"digusur"

c. Poems of Ucapkan Kata-katamu

In the poem Ucapkan Kata-katamu, Wiji Thukul uses concrete words such as "ditenggelamkan keputusan" which has the meaning of falling into trouble because of decisions made by certain parties. In the poem Ucapkan Kata-katamu, Wiji Thukul also uses the word "menganga" which means to open the mouth.

d. Poetry Catatan 88

The poem Catatan 88 created by Wiji Thukul uses connotative words. The word is "dibungkus gurauan" which has the meaning of aspiration wrapped or filled with a joke, so that it can give a subtle satire to the leader. 
e. Poetry Tanah

Wiji Thukul seems to explain what people expect from a city without green plants that are turned into factories and roads. life for the weak people because only lucky people or the elite feel lucky. Wiji Thukul in this piece of poetry uses diction or the choice of connotative words.

"apa yang kita harap"

"dari cerobong asap besi"

f. Poetry Di Bawah Selimut Kedamaian Palsu

Wiji Thukul uses connotative words. "kongkalikong with "kaum cukong""'has the meaning of many people who are dishonest and not open. People who conspire with someone who has a lot of money with the aim of making profits to the detriment of others.

"kongkalikong"

"dengan kaum cukong"

g. Poerty Untuk Adik

Wiji Thukul uses the word as if to explain that with knowledge and good character, a person will be able to deal wisely with all the suffering that occurs.

"waktu yang bijak-bestari"

"kan sudah mengajari kita"

h. Poetry Bunga dan Tembok

The meaning of the word "tirani" which is meant by Wiji Thukul is power that is used arbitrarily. From this piece of poetry, Wiji Thukul seems to explain wherever arbitrary power must be overthrown or eliminated.

" dalam keyakinan kami”"

"dimana pun tirani harus tumbang!"

i. Poetry Sajak Suara

In the poem Sajak Suara, Wiji Thukul's choice of words uses connotative words. A connotative word that describes an aspiration or an expression full of unstoppable doubts from within the recesses of the soul.

" namun siapa mampu menghentikan nyanyian bimbang"

" dan pertanyaan-pertanyaan dari lidah jiwaku"

j. Poetry Peringatan

The depiction in the stanza of Wiji Thukul's poem seems to explain that if the opinion of the ruler cannot be refuted even if it is wrong, then all truth and goodness will be lost. So that what remains is only the rules that are not in accordance with what they should be. From the fragment of the poem, it seems to give a warning to the higher-ups to take into account the opinions or aspirations of the people.

"dan bila omongan penguasa"

"tidak boleh dibanta"

"kebenaran pasti terancam"

k. Poetry Ibu

Wiji Thukul explained using the word "Beku". Beku here is not meant by cold and lumps like ice. But frozen is the time that stands still or stops and dies. 
"waktu hidup yang tak kubiarkan beku"

"itulah tanda baktiku kepadamu"

1. The Poetry of Derita Sudah Naik Seleher

From a fragment of his poem describes how he felt the wounds all over his body. Long wounds on the skin as if the scars from a whip were still felt all over his body. But the wound he felt only equalized what he felt or seemed to be happening in his body. He seemed to be tormented by a real physical blow, but he was tormented mentally and spiritually by the wisdom of the higher-ups.

"luka sudah kaubilurkan"

"ke sekujur tubuhku"

m. Poetry (Tanpa Judul)

From a fragment of his poetry the poet uses the word "jarah" which means spoil. Wiji Thukul explained how he felt about his confiscated books.

"rumahku kalian geledah"

"buku-bukuku kalian jarah"

n. Poetry Menolak Patuh

In his poetry, Wiji uses the fragment of diction above to explain that the spoken words cannot be prevented or silenced. Everyone has the right to express what they want to say.

"dan terbitnya kata-kata dalam diriku"

"tak bisa dicegah"

o. Poerty Aku Masih Utuh dan Kata-Kata Belum Binasa

In his poetry, Wiji Thukul uses the phrase "ditusuk-tusuk sepi" which is a connotative word that gives rise to a sense of loneliness that describes the poet's ideas or expressions in describing the poet's inner atmosphere and condition. The phrase "ia tak mati-mati" is a word that describes a spirit that is not extinguished.

"ditusuk-tusuk sepi"

"ia tak mati-mati"

- Analysis of the use of language styles contained in the Anthology of Aku Ingin Menjadi Peluru

a. Poerty Nyanyian Akar Rumput

In the Nyanyian Akar Rumput Poem, Wiji Thukul uses personification metaphors. Wiji Thukul wrote the sentence "kami rumput". The grass that Wiji Thukul meant was a wasted thing. Wiji Thukul equates inanimate objects with humans. The figure of personification is found in the word "butuh tanah" which refers to plants that need soil. Similarly, humans need a place to live to survive.

"kami rumput"

"butuh tanah"

b. Poetry Ucapkan Kata-Katamu

The figurative language of the epic parable is shown in the word "seperti batu." The epic parable describes deeper than its comparison, namely stone. The stone referred to 
by Wiji Thukul is an inanimate object or thing that can be thrown away and picked up at will. Or it's the same with grass that can be pulled out because it can be annoying. "kau akan diperlakukan seperti batu"

"dibuang dipungut"

"atau dicabut seperti rumput"

c. Poems of Monumen Bambu Runcing

The important thing that was conveyed by Wiji Thukul in the poem Monument Bambu Runcing was " menuding dan berteriak merdeka ". Alleging that what Wiji Thukul meant was pointing at the Monumen Bambu Runcing and berteriak merdeka. In his poetry, Wiji Thukul wants to convey the desire for freedom.

"di tengah kota"

"menuding dan berteriak merdeka"

d. Poetry Catatan 88

Wiji Thukul means that so many plans cannot be realized due to circumstances. The many plans keep growing so that they pile up like graves. The grave in question is a quiet and quiet place. How many bodies are there but no life. All plans are just a dark dream and cannot be realized.

"saban malam"

"rencana-rencana menumpuk jadi kuburan"

e. Poetry Tanah

From a fragment of his poem entitled Tanah, Wiji Thukul seems to tell how painful a city is without afforestation. Living things feel incomparable suffocation, due to pollution everywhere. Just as animals need a place, birds need a nest for shelter. Humans also need plants and fertile soil to survive. Ordinary people need a place to stay for shelter is hard to come by. But some people find it easy to get land and even sell it at a high price.

"seekor burung kecil menanti induknya"

"di dalam sarangnya yang gemeretak"

"dimakan sapi"

f. Poetry Di Bawah Selimut Kedamaian Palsu

Wiji Thukul explained that not only the mouth can be called a muzzle. Weapons can also be referred to as muzzles, aka as if they can convey what is ordered.

" di mana-mana moncong senjata"

"berdiri gagah"

g. Poerty Untuk Adik

Wiji Thukul uses the figure of speech to explain the meaning of whether we will become like that junk bike that has no value at all. Being belittled and wasted is like something that deserves to be destroyed.

"apakah nasib kita akan seperti"

"sepeda rongsokan karatan itu?"

h. Poetry Bunga dan Tembok

From this passage, Wiji Thukul also seems to explain whether ordinary people are people who are not wanted by higher-ups to live and must be removed. Where high- 
ranking officials at will take and even rob the rights of ordinary people for personal gain.

"seumpama bunga"

"kami adalah bunga yang tak"

"kau kehendaki adanya"

i.Poerty Sajak Suara

The figure of speech that was used by Wiji Thukul seemed to explain as if someone was threatening high-ranking officials who were not in line with the regulatory system to quit their position. Otherwise, destruction will befall him. This figure of speech can be explained in the following snippet of poetry:

"apabila engkau tetap bertahan"

"aku akan memburumu seperti kutukan"

j.Poetry Peringatan

From a fragment of his poem the poet uses the word "ditimbang" which is usually the word weighed is used to determine the weight of something. Wiji Thukul means the suggestion is rejected without thinking first.

"apabila usul ditolak tanpa ditimbang"

"suara dibungkam kritik dilarang tanpa alasan"

k. Poerty Ibu

From the fragment of the poem, Wiji Thukul also seems to explain whether children are something that must be forced to provide benefits in the future as a sign of paying back to parents. So many children are demanded by parents to be what they want. Even though children also have the right to dream and live their life the way they want as long as it's good.

"apakah anak adalah tabungan"

"bisa sesuka hati dipecah kapan saja"

1.The Poetry of Derita Sudah Naik Seleher

From his poetry, the poet Wiji Thukul compares himself to a rock. The word hardened is commonly used to describe rock. But what Wiji Thukul meant was hardening in his poetry, not stone. Instead, Wiji Thukul wants to explain that the more he is bullied, the more he will progress and will not tremble. The spirit rises in his soul and will never give up.

"kausiksa aku sangat keras"

"hingga aku makin mengeras"

m. Poetry (Tanpa Judul)

Wiji Thukul in his poem (Tanpa Judul) uses synecdoki figurative language to describe what he experienced. From a fragment of his poem, Wiji Thukul explains how his house in the village was searched when he was on the run or in exile.

"kuterima kabar dari kampong"

"rumahku kalian geledah"

n. Poetry Menolak Patuh 
Simile language style is used to equate one thing with another using comparative words: such as, bak, laksan, etc. Simile is used by the poet to describe something that is felt by humans, such as joy with animals such as butterflies that fly as they please.

"kegembiraanku tak akan berubah"

"seperti kupu-kupu"

o. Poerty Aku Masih Utuh dan Kata-Kata Belum Binasa

Synecdochi is used to express or state some for all (Pars Pro Toto). Synecdoki is used by Wiji Thukul to describe the expression " kata-kata itu selalu menagih ". The word to collect is meant by Wiji Thukul is not feeling enough or lacking. Words that always relentlessly insist you have to keep holding on.

"kata-kata itu selalu menagih"

"padaku ia selalu berkata"

- Analysis of the use of images (images) contained in the Anthology of Poetry Aku Ingin Menjadi Peluru

a. Poems of Monumen Bambu Runcing

In the poem Monument Bambu Runcing, Wiji Thukul conveyed the words "dihalang petugas keamanan". From this stanza, the reader gets a picture of the movement that occurs, as if the reader can see someone being blocked by security officers. So it can be concluded, Wiji Thukul in the poem Monument Bambu Runcing uses motion imagery.

"walau berulang-ulang"

"dihalau petugas ketertiban"

b. Poerty Nyanyian Akar Rumput

In his poetry, Wiji Thukul raises the word "dengar", where with this word the reader can imagine as if hearing what the poet said. The word hear was taken by Wiji Thukul as if to remind someone to listen to what he had to say in order to join in defending the truth for what the president had done.

"dengar!

"ayo gabung ke kami"

"biar jadi mimpi buruk presiden"

c. Poerty Ucapkan Kata-katamu

In the poem Ucapkan Kata-katamu, Wiji Thukul uses the word "mengucapkan". The word uttering is included in auditive imagery, where the reader seems to be able to hear what is being said or something is being said. It is explained by the word "mulutmu", which when someone speaks with their mouth, the ear will process hearing.

"jika kau tahan kata-katamu"

"mulutmu tak bisa mengucapkan apa maumu" 
d. Poetry catatan 88

Wiji Thukul uses the word odor to explain to readers how the smell of tobacco and the smell of sweat is on the body. That's how Wiji Thukul conveyed what he felt when he wrote the poem catatan 88 .

"menyanyi menyabarkan diri"

"bau tembako dan keringat di badan"

e. Poerty Land

From a fragment of his poem, it seems as if Wiji Thukul invites us to see what is happening now. Many trees are cut down, plants are destroyed to build buildings and even factories. The destruction of forests is everywhere, resulting in extraordinary forest fires. So that we can find aridity around us and find a little green space.

"jika sawah diratakan"

"rimbun semak pohon dirubuhkan"

f.Poetry Dibawah Selimut Kedamaian Palsu

Wiji Thukul is a poet who is good at conveying what he feels through his work. With the imagery of motion that he pours out, it makes readers love his poems even more, because his poetry can be easily understood and understood by readers.

"di desa-desa"

"rakyat dipaksa"

"menjual tanah"

g. Poerty Untuk Adik

Wiji Thukul in his poem uses the word "bergulat", so that when the reader reads the word, it is as if the reader can imagine someone who is fighting or struggling to win something.

"jangan menyerahkan diri pada ketakutan"

"kita akan tersu bergulat"

h. Poetry Bunga dan Tembok

From the fragments of his poetry, it is as if the reader can see or imagine how someone whose house and land were confiscated. It was as if the incident was recorded in their minds and they could see what was happening. Even though it's only from fragments of words that the poet pours through his poetry.

"engkau lebih suka membangun"

"rumah dan merampas tanah"

i.Poetry Sajak Suara

In his poetry, Wiji Thukul means that voices or aspirations cannot be suppressed and silenced because all people have the right to express their opinion on something that is not working properly. The image is contained in a fragment of poetry.

"suara-suara itu tak bisa dipenjarakan"

"disana bersemayam kemerdekaan"

j.Poetry Peringatan

Wiji Thukul in his memorial poem utilizes auditive imagery, which is clarified by a snippet of poetry. From the verse "dan bisik-bisik", the poet seems to imagine to the reader someone who seems to be whispering in his ear. It is as if the reader's 
imagination can hear the narrative that is expressed and the sound naturally heard by the ear.

"dan berbisik-bisik"

"ketika membicarakan masalahnya sendiri"

k. Poetry Ibu

In his poetry, Wiji Thukul uses the word walking, which indirectly makes the reader imagine how someone walks or even himself when walking. Or even time that passes or runs from time to time.

"juga bukan yang bisa dan sudah dipilih"

"oleh yang berjalan itu sendiri?"

1.The Poetry of Derita Sudah Naik Seleher

The imagery used by Wiji Thukul in the poem Derita Sudah Naik Seleher is tactile imagery. From a fragment of his poem, Wiji Thukul seems to explain through imagining how bleeding lips are. As if the reader can feel how it feels like bleeding lips.

"darah sudah kauteteskan"

"dari bibirku"

m. Poerty (Tanpa Judul)

The imagery used by Wiji Thukul describes how someone in a uniform is waiting for him and looks for him every day while carrying a rifle. From the pieces of poetry that he conveys, it seems as if the reader can imagine it.

"setiap hari di mana-mana"

"sambil nenteng-nenteng senapan"

n. Poetry Menolak Patuh

Wiji Thukul uses imagery to depict a soldier on the highway. So that the imagination of the reader seems to be able to see how a soldier is on the highway.

"tentara di jalan-jalan raya"

"pidato kenegaraan atau siaran pemerintah"

o. Poetry Aku Masih Utuh dan Kata-Kamu Belum Binasa

Wiji Thukul uses motion imagery to describe how someone is sweating and jostling. So that when the reader reads the stanza, the reader then imagines what happened.

"puisiku bukan puisi"

"tapi kata-kata gelap"

"yang berkeringat dan berdesakan"

\section{- Utilization of word choice (diction) Poetry Anthology Aku Ingin Menjadi Peluru}

The use of Wiji Thukul's words, which are so intelligent and straightforward, can express the characteristics of his poetry which is so firm but has extraordinary beauty in meaning. The use of the words chosen by Wiji Thukul is also not too poetic, because his poems contain nationalist values. 


\section{- Utilization of the language style found in the Anthology Aku Ingin Menjadi Peluru}

Dick Hartono and Rahmanto (in Pradopo, 2020: 4) suggest that language style is a typical way used by a person to express himself as a writer. This is what is seen in Wiji Thukul's poems which are specific as a form of people's aspirations.

The use of language style (majas) can affect the style and beauty contained in poetry. Wiji Thukul's anthology I Want to Be a Bullet, in addition to using the more dominant figure of speech, also uses many language styles such as simile, synecdoche, metaphor, personification and allegory.

\section{- Utilization of images (images) contained in the Anthology Aku Ingin Menjadi Peluru}

Wiji Thukul. Nurgiyantoro (2019: 282) argues that motion imagery is an image related to the concretization of motion objects that can be seen by the eye. Motion imagery describes something that is not actually moving but is described as an object that can move. Imagery can make a poem feel alive. In the anthology I Want to Be a Bullet, Wiji Thukul uses imagery as a description of various sensory experiences evoked by words from what is experienced or felt.

\section{CONCLUSION}

Based on the research and discussion conducted on the study of stylistics (study of diction, language style, and imagery) on the fifteen poems in the Anthology of Aku Ingin Menjadi Peluru the following conclusions can be obtained:

1. Based on the analysis of word choice in the Anthology of Aku Ingin Menjadi Peluru, the choice of diction is obtained from the use of concrete words, and connotative words. The results of the analysis show that Wiji Thukul uses a lot of concrete words, which aims to clarify his poems but still have a beauty value. And has the meaning of honesty, sincerity and something as it is.

2. Based on the style analysis in the Anthology of Aku Ingin Menjadi Peluru, Wiji Thukul uses many and varied styles of language. Among the existing language styles such as simile, metaphor, personification, allegory, and others. Wiji Thukul dominantly uses synecdoki language style (majas). The use of synecdoki figure of speech can give the impression of beauty in a poem. Thus, the use of synecdoche figure of speech can make the Poetry Anthology Aku Ingin Menjadi Peluru clear and real, but still interesting. Based on the data and stylistic analysis in the Anthology of Aku Ingin Menjadi Peluru, the researcher concludes that Wiji Thukul aims to represent the feelings and thoughts that he expresses through his poetry. The style of language in the Poetry Anthology Aku Ingin Menjadi Peluru serves to bring poetry to life, the expression of meaning becomes more impressive, more real, clearer, more interesting and creates an element of beauty. Wiji Thukul uses all language styles very precisely.

3. Based on image analysis in the Anthology of Aku Ingin Menjadi Peluru, Wiji Thukul uses auditive imagery, visual imagery, motion imagery, olfactory imagery and tactile imagery. However, in his poetry, Wiji Thukul uses the imagery of motion more. With the imagery of motion that he uses, it can add to the beauty of poetry. The five senses or the reader's imagination can explore what Wiji Thukul conveys through motion imagery. 


\section{REFERENCES}

Adhani, Agnes. (2017). Kosa Kata Bahasa Indonesia. Yogyakarta: Textium.

Fransori, Arinah. (2017). Analisis Stilistika Pada Puisi Kepada Peminta-Minta Karya Chairil Anwar. Jurnal Program Studi Pendidikan Bahasa dan Sastra Indonesia, Vol 9 (1), 12 halaman. Tersedia: https://core.ac.uk/download/pdf/322552555.pdf (1 Desember2020)

Istiqomah, Nuriana dkk. (2014). Sikap Hidup Orang Jawa Dalam Novel Orang-Orang Proyek Karya Ahmad Tohari. Jurnal Sastra Indonesia, 2 halaman. Tersedia:https://journal.unnes.ac.id/sju/index.php/jsi/article/view/3964/3593

(1 Desember2020)

Heru, Kurniawan. (2012). Teori, Metode, dan Aplikasi Sosiologi Sastra. Yogyakarta: Graha Ilmu.

Imani, Wafda Nurul,dkk. (2020). Konflik Batin Dan Nilai Pendidikan Novel Di Tanah Lada Karya Ziggy Zezsya Azeoviennazabrizkie Serta Relevansinya Dengan Pembelajaran Sastra di SMA. Basatra:Jurnal Bahasa, Sastra dan pengajarannya, vol 8 (2), 299 halaman.Tersedia: $\quad$ https://jurnal.uns.ac.id/Basastra/article/view/45196/pdf (07 April2021)

J.Pohan. (2019). Menyimak Sastra Feminisme Kekinian: Suatu Kajian Kritik Ssatra Hermeneutik : Jurnal Ilmiah Pendidikan Bahasa dan Sastra Indonesia, vol (1), 8 halaman. Tersedia: https://ejurnal.univalabuhanbatu.ac.id/index.php/kontras (07 April2021)

Laila, Aruna. (2016). Citraan Dalam Kumpulan Puisi Mangkutak Di Negeri Prosaliris Karya Rusli Marzuki Saria. Jurnal Program Studi Pendidikan Bahasa dan Sastra Indonesia, Vol 2, 14 halaman. Tersedia: https://media.neliti.com/media/publications/80809-IDcitraan-dalam-kumpulan-puisi-mangkutak-d.pdf (1 Desember2020)

Mudjiyanto, Bambang \& Nur, Emilsyah. (2013). Semiotika Dalam Metode Penelitian Komunikasi. Jurnal Balai Pengkajian dan Pengembangan Komunikasi dan Informatika, Vol 16 (1), 2 halaman. Tersedia: https://jurnal.kominfo.go.id/index.php/pekommas/index (27 Januari 2021)

Munir, Saiful. (2013). Diksi dan Majas Dalam Kumpulan Puisi Nyanyian Dalam Kelam Karya Sutikno W.S:Kajian Stilistika. Jurnal Sastra Indonesia, 10 halaman.Tersedia:https://journal.unnes.ac.id/sju/index.php/jsi/article/view/2437/2238 (15 November2020)

Nurgiyantoro, Burhan. (2019). Stilistika. Yogyakarta: Gajah Mada University Press.

Nurmayani, Eva \& Aini, Roqyal. 2019. Bentuk Citraan Dalam Kumpulan Puisi Penangkar Bekisar Karya Kiki Sulistyo:Kajian Pustaka. Elkatarie:Jurnal Pendidikan dan Sosial, Vol 1 (2), 11 halaman. Tersedia: https://core.ac.uk/download/pdf/229130559.pdf (1 Desember 2020) 
Email : editorijhess@gmail.com

Oktaviantina, Adek Dwi. 2019. Citraan Dalam Kumpulan Puisi Abdul Salam HS "Malaikat Waringin". Jurnal Bahasa, 14 halaman. Tersedia: https://jurnalbebasan.kemdikbud.go.id/jurnal/index.php/bebasan/article/view/118/87 (1 Desember 2020)

Pradopo, Rachmat Djoko. (2020). Stilistika. Yogyakarta:Gadjah Mada University Press.

Pradopo, Rachmat Djoko. (2019). Pengkajian Puisi. Yogyakarta:Gadjah Mada University Press.

Pratiwi, Dian. (2018). Analisis Sastra. Yogyakarta:Graha Ilmu.

Ratna, Nyoman Kutha. (2013). Paradigma Sosiologi Sastra. Yogyakarta: Pustaka Belajar

Sugiyono. (2017). Metode Penelitian Pendidikan (Pendekatan Kuantitatif, Kualitatif, dan $R \& D$. Bandung: Alfabeta.

Suroto (2015). Teori dan Bimbingan Apresiasi Sastra Indonesia. Jakarta: Erlangga 